\title{
Weathering of metallurgical slag heaps: multi-experimental approach of the chemical behaviours of lead and zinc
}

\author{
N. Seignez ${ }^{1}$, D. Bulteel ${ }^{2}$, D. Damidot ${ }^{2}$, A. Gauthier ${ }^{1}$ \\ \& J. L. Potdevin ${ }^{1}$ \\ ${ }^{1}$ UMR 8110 PBDS, University of Lille I, France \\ ${ }^{2}$ Civil Engineering Department, Ecole des Mines de Douai, France
}

\begin{abstract}
The production of lead and zinc in the Lead Blast Furnaces of metallurgical factories produces a huge amount of slags. These slags are a $\mathrm{Pb}-\mathrm{Zn}$-rich vitreous material with a $\mathrm{CaO}-\mathrm{SiO}_{2}-\mathrm{FeO}$-rich glass matrix containing metallic lead droplets and $\mathrm{Fe}$ oxides. The resulting slag heap is exposed to weathering and can be a source of chemical pollution. In this study, different experiments allow the study of the behaviour of $\mathrm{Zn}$ and $\mathrm{Pb}$ during the weathering of slags. First, a Teflon leaching column (ascending flux) equipped with samplers in order to collect the fluid inside and at the outlet of the column was used. The second experiment was a pure water flow on a polished section of slag. The third system was an outdoor experiment where the slag was exposed to natural weathering comparable to the heap. ICP-AES and ESEM-EDS have been used to follow the evolution of the water chemistry and the slag compositions and textures during the experiments. Two episodes of $\mathrm{Pb}$ and $\mathrm{Zn}$ releases were noticed at the column outlet. A first brief episode might be caused by some colloids or slag dust releases. The second episode essentially results from glass and metallic lead dissolution. Hydrocerusite locally appeared in the column. Investigations carried out on the polished sections show complex alteration patterns. They suggest that the behaviour of the glass and of minor phases is closely linked to the local structure and composition at the slag surface. Outdoor experiments show slower kinetics than in the other experiments, but the alteration type is similar despite some differences.
\end{abstract}

Keywords: metallurgical slag, iron-silica-lime glass, waste leaching, lead and zinc releases. 


\section{Introduction}

In the industrial basin of the Nord-Pas-de-Calais (France), blast and smelting furnaces have been used to produce lead and zinc during the last century. The Noyelles-Godault factory has generated a huge amount of waste. In its Lead Blast Furnace production unit, the production of 1 ton of metal generated approximately 1 ton of metallurgical slags [1]. These slags contain several percents of $\mathrm{Pb}$ and $\mathrm{Zn}$ [1-3] and others pollutants as $\mathrm{Cr}, \mathrm{Cd}, \mathrm{As}$ [2]. They were not reused as raw materials. Four million tons of such primary smelting slags were then stored in a slag heap spread on $1 \mathrm{~km}^{2}$ next to the factory [2].

The pollutant releasing abilities of various lead-zinc metallurgical slags have already been discussed in numerous previous works. Indeed, contaminant mobility has been tested in different environments in order to evaluate the ways slags can be reused as raw materials or just to evaluate the stabilization abilities of their storage conditions. The studies concerning the leachability in concretelike conditions [3, 4], when used as road materials [5], in pure or acidic water $[2,4,6,7]$ or in contact with organic solutions [8] are more or less common. More specific studies on glass leaching abilities have also shown that the glass composition [9-12], the local environment of iron [13, 14] and the $\mathrm{pH}$ and temperature [10] are very important parameters concerning the leaching resistivity in lime-silica glasses. Secondary phase formations $[2,6,7,8,15]$ and sorption phenomena on glass or crystalline phases [16-20] can also play an important role on the pollutant mobility/immobility.

Slag heaps are generally not protected from rainfalls. Slags are thus exposed to weathering conditions. The most accessible part of the heap for the water may be governed by flow conditions. Yet, most of previous studies were made in batch conditions. To our knowledge, no study using the present Lead Blast Furnace slags in open flow system using pure water has been performed.

This work proposes to follow $\mathrm{Zn}$ and $\mathrm{Pb}$ mobility in two original laboratory leaching experiments in pure water flow conditions and to compare the laboratory results with slag alteration under natural weathering conditions in draining and non-draining conditions.

\section{Materials and methods}

\subsection{Slag characterization}

Slags are generally smaller than $2 \mathrm{~mm}$. The size distribution is lognormal with a $500 \mu \mathrm{m}$ dominant class [1]. The phase arrangements in the slags have already been described at micrometric scale by Deneele [2] estimated the waste is composed at $80 \%$ (in volume) of a $\mathrm{FeO}-\mathrm{SiO}_{2}-\mathrm{CaO}$ glass with few percents of $\mathrm{Pb}$ and $\mathrm{Zn}$. Slags also contain $19 \%$ of crystallized iron oxides and $1 \%$ of plurimicrometric droplets of metallic lead. Automorphous spinels are spread into the iron-lime-silica glass matrix. This glass also contains few mass percents of others elements like $\mathrm{Al}, \mathrm{Mg}, \mathrm{Na}$ and $\mathrm{K}$. Spinels have a chromium rich centre $\left(\mathrm{MgCr}_{2} \mathrm{O}_{4}\right)$ while the composition evolves to franklinite $\left(\mathrm{ZnFe}_{2} \mathrm{O}_{4}\right)$ or sometimes 
in magnetite $\left(\mathrm{Fe}^{2+} \mathrm{Fe}^{3+}{ }_{2} \mathrm{O}_{4}\right)$ to the borders [2]. Plurimicrometric and dendritically shaped oxides have also been described as $\mathrm{Zn}$ substituted wüstite $\left(\mathrm{Fe}_{0.85-\mathrm{x}} \mathrm{Zn}_{\mathrm{x}} \mathrm{O}\right)$ $[1,2]$. Metallic lead droplets which sizes range between $1 \mu \mathrm{m}$ and $400 \mu \mathrm{m}[1,2]$ have also been identified.

\subsection{Column test}

The LBF slags used here come from Noyelles-Godault (France). A significant volume of $300 \mathrm{~kg}$ of slags has been sampled at the end of the metallurgical process during 1 month (frequency: 2 or 3 samplings for a week) [2]. The diameters (d) of the slag used for this test range between 2 and $2.5 \mathrm{~mm}$. The slag surfaces have been cleaned from most of dust by three successive ultra-sonic baths in alcohol.

The column is a $220 \mathrm{~mm}$ high PTFE cylinder with an internal diameter (D) of $25 \mathrm{~mm}$. The $\mathrm{D} / \mathrm{d}$ ratio of 10 and the column height must create a homogeneous flux. Teflon is used to avoid sorption phenomena on the column wall. At three levels of the column, openings filled with septa allow to do in-situ leachate samplings with specific needles [15]. In front of these openings, PTFE cylinders called samplers are placed (Figure 1). Hydrodynamic tests using tracer have shown, they do not create any notable disturbance on the ascending flux. At the column inlet, a Teflon piece is placed to homogenize the flux. The column contains about $150 \mathrm{~g}$ of slags. The column is connected to a pump (Figure 2) and a pure water reservoir $(\mathrm{pH}=5.6)$. The pump provides a constant flow at $60 \mathrm{ml} \cdot \mathrm{h}^{-1}$. At the column outlet, a fraction collector driven by a computer allows to sample the leachate with a high frequency (for example, 1 sample by hour).
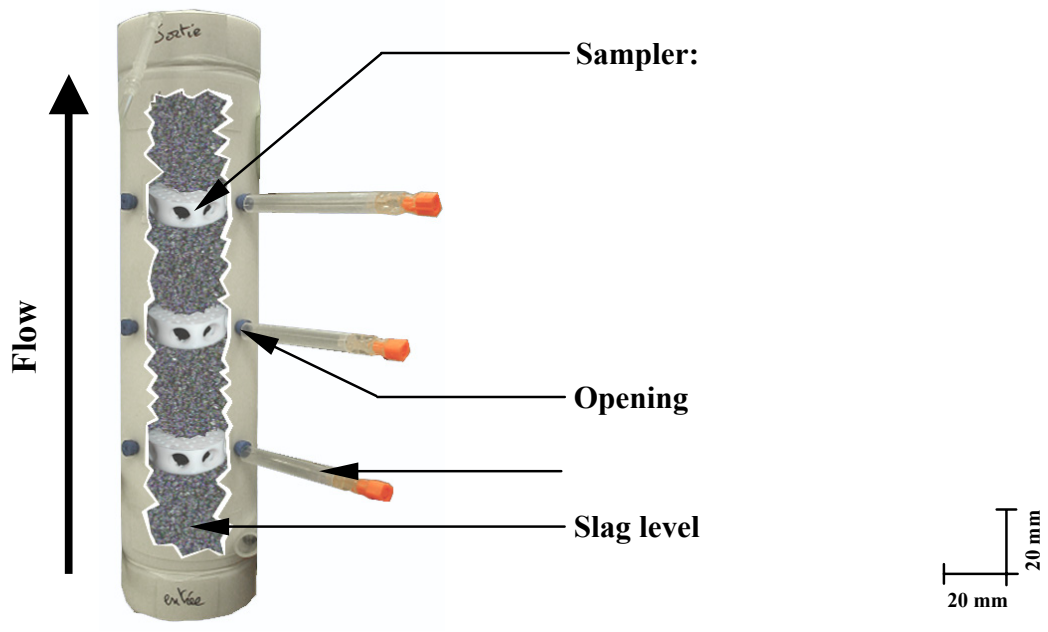

Figure 1: Photomontage showing the column interior and exterior. 
A Thermo ICP-AES has been used to estimate the concentration of the following elements: $\mathrm{Al}, \mathrm{As}, \mathrm{Ba}, \mathrm{Ca}, \mathrm{Cd}, \mathrm{Cr}, \mathrm{Cu}, \mathrm{Fe}, \mathrm{K}, \mathrm{Mg}, \mathrm{Mn}, \mathrm{Na}, \mathrm{Ni}, \mathrm{Pb}, \mathrm{Si}$, $\mathrm{Ti}, \mathrm{Zn}$. The detection level is approximately about $20 \mathrm{ppb}$ for the majority of the analysed elements. $\mathrm{Cu}$ detection level is a little higher: $50 \mathrm{ppb}$.

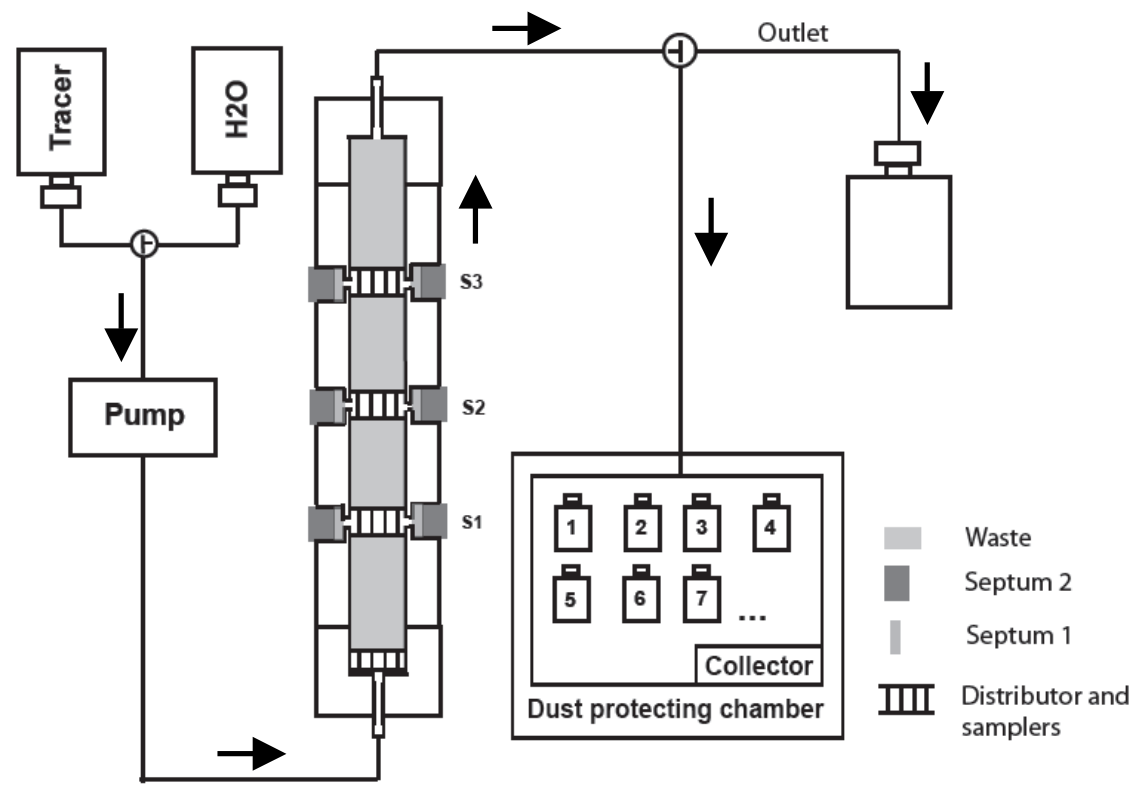

Figure 2: $\quad$ Scheme of the experimental device.

\subsection{Polished section test}

This leaching experiment is very close to the one described before. The column is replaced by a polished section container. The container is supplied with pure water connected to a peristaltic pump which provides a constant flow of $60 \mathrm{ml} \cdot \mathrm{h}^{-1}$. The sections are $60 \mathrm{~mm}$ long and $20 \mathrm{~mm}$ wide. To make these polished sections, slag grains are included in an epoxy resin and are polished in order to expose slag surfaces $(40 \%$ of the total upper face). There are approximately $3 \mathrm{~mm}$ between the section surface and the upper side of the container. Then, the Darcy velocity in the container is about $1 \mathrm{~m} . \mathrm{h}^{-1}$. The sections were observed by ESEM 15 and 26 days after the beginning of the experiment. The chemical analyses have been obtained at 26 days with ESEM-EDS.

\subsection{Outdoor weathering}

In this experiment, draining and non-draining conditions which may occur in the heap are simply reproduced with the help of specific jars. In each sort of experiments polished sections were exposed to climatic conditions. The evolution of the slag aspect was followed by ESEM. 


\subsection{Electron microscopy}

The morphology and composition of slag sections before and after alteration was studied using a FEI Quanta 200 Environmental Scanning Electron Microscope (ESEM). The tungsten electron source is used at $20 \mathrm{kVolt}$. The spatial resolution of its X-ray Energy Dispersive System (EDS) probe is about $1 \mu \mathrm{m}^{3}$. The accuracy of the analyses can reach $0.5 \%$ (in weight) in high vacuum. In order to be reused, the polished sections were not carbon coated as usual and were inserted in the ESEM chamber in low vacuum mode. The relatively low pressure in ESEM chamber $(\leq 0.45$ Torr) reduces the analysis accuracy. Then, only the global trend has been considered.

\section{Results and discussion}

\subsection{Column test}

\subsubsection{Leachate chemistry}

During the first hours of experiment, the $\mathrm{pH}$ value at the column outlet is enhanced to 7 and increases to 7.8 . The $\mathrm{pH}$ (Figure $3 \mathrm{~A}$ ) rapidly decreases to reach a value near to 6 (i.e. near pure water $\mathrm{pH}$ ). Concerning ICP-AES analyses, only four elements $(\mathrm{Ca}, \mathrm{Si}, \mathrm{Pb}$ and $\mathrm{Zn})$ were detected in relatively high amount in the leachates. No iron was detected. In the first hours, $\mathrm{Pb}, \mathrm{Zn}$ and $\mathrm{Ca}$ releases (Figure $3 \mathrm{~B}, \mathrm{C}, \mathrm{D}$ ) may be linked to the $\mathrm{pH}$ variations.

Indeed, the concentrations of $\mathrm{Pb}$ and $\mathrm{Ca}$ in the first samples were the highest measured during the test. This can be connected to dust cleaning at the slag surfaces. Indeed, tests have shown that dust is very difficult to keep out before the experiments. After the $\mathrm{pH}$ stabilization at $6, \mathrm{Ca}, \mathrm{Pb}$ and $\mathrm{Zn}$ progressively reached an approximately constant releasing level at $0.5,0.15$ and $0.15 \mathrm{ppm}$ respectively. Si releasing slowly increases during the experiments (Figure $3 \mathrm{E}$ ) to reach $0.45 \mathrm{ppm}$ at $\mathrm{t}_{1400 \mathrm{~h}}$.

The $\mathrm{Ca}$ and $\mathrm{Si}$ loss indicate the glass matrix alteration was persistent throughout the experiment. Considering the electron microscopy observations, $\mathrm{Ca}$ and $\mathrm{Si}$ may not be fixed in secondary phases. The $\mathrm{Ca}$ releasing rate is around $30 \mu \mathrm{g} \cdot \mathrm{h}^{-1}$ in the second part of the experiment and the Si releasing rate ranges between 10 and $30 \mu \mathrm{g} \cdot \mathrm{h}^{-1}$. The $\mathrm{Pb}$ and $\mathrm{Zn}$ releasing rate is around $10 \mu \mathrm{g} \cdot \mathrm{h}^{-1}$ in the second part of the experiments

\subsubsection{Waste observations at $t_{\text {end }}$}

ESEM-EDS analyses show leaching evidences on the glass and, particularly, near the column inlet. Some glass fields are highly fractured (Figure $4 \mathrm{~A}$ ), however it may be due to desiccation of hydrolysed glass in the ESEM chamber. Traces of glass alteration are less important when slags are situated further from the column inlet. EDS analyses have shown the further from the inlet the glass is, the less important the $\mathrm{Si}$ and $\mathrm{Ca}$ loss is. Then, glass alteration essentially occurs at the bottom of the column (Table. 1) Leachate compositions are closely linked to this phenomenon. Indeed, the in-situ samplings show that the leachate chemistry does not really change between the three samplers and the outlet. 
Conversely, superficial lead droplets often react in the entire column. Punctually, big lead droplets are not totally dissolved and plurimicrometric carbonates have been formed near (Figure $4 \mathrm{~B}$ ). The iron oxides seem to be relatively stable. Thus, $\mathrm{Zn}$ may not be released from the dendritical wüstite spread in the glass. Its source may be only the glass.
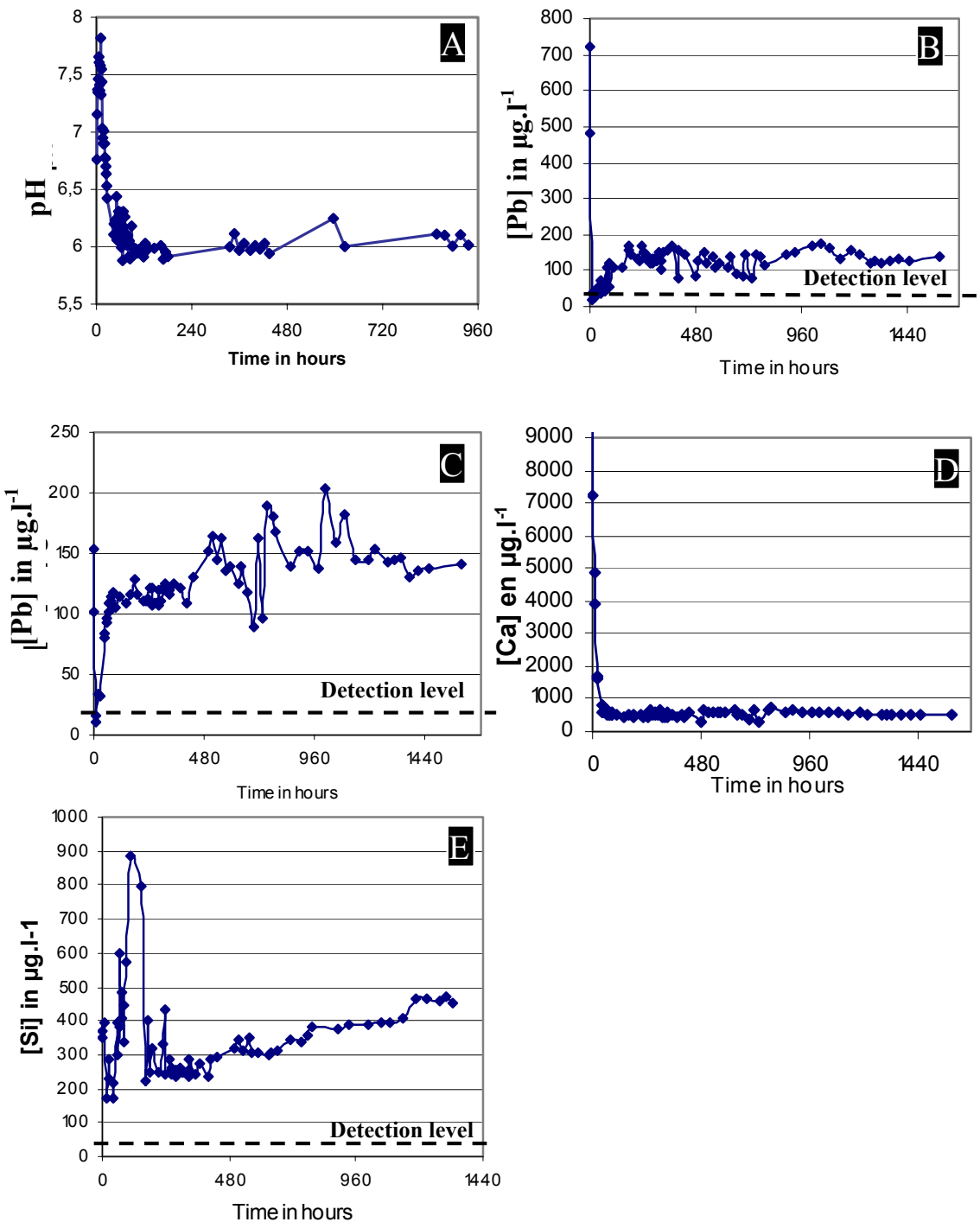

Figure 3: Graphs showing the $\mathrm{pH}$ evolution at the column outlet (A). Graphs (B), (C), (D) and (E) respectively show $\mathrm{Pb}, \mathrm{Zn}, \mathrm{Ca}$ and Si releasing during the experiment. 


\subsection{Polished section tests}

ESEM showed the same type of glass alteration (Figure $4 \mathrm{C}$ ) and lead carbonate formations as in the column test. Laminar flux encountered in this test enhanced micro-canyon formation (by glass alteration) less observed in column test. Glass can be kept fresh in some saved regions. Nevertheless, $\mathrm{Ca}$ and $\mathrm{Si}$ losses correspond to altered glass regions similar to these observed in the column (Table 1). Highly fractured and lightening zones often correspond to regions downstream dissoluting big lead droplets (Figure $4 \mathrm{D}$ ).
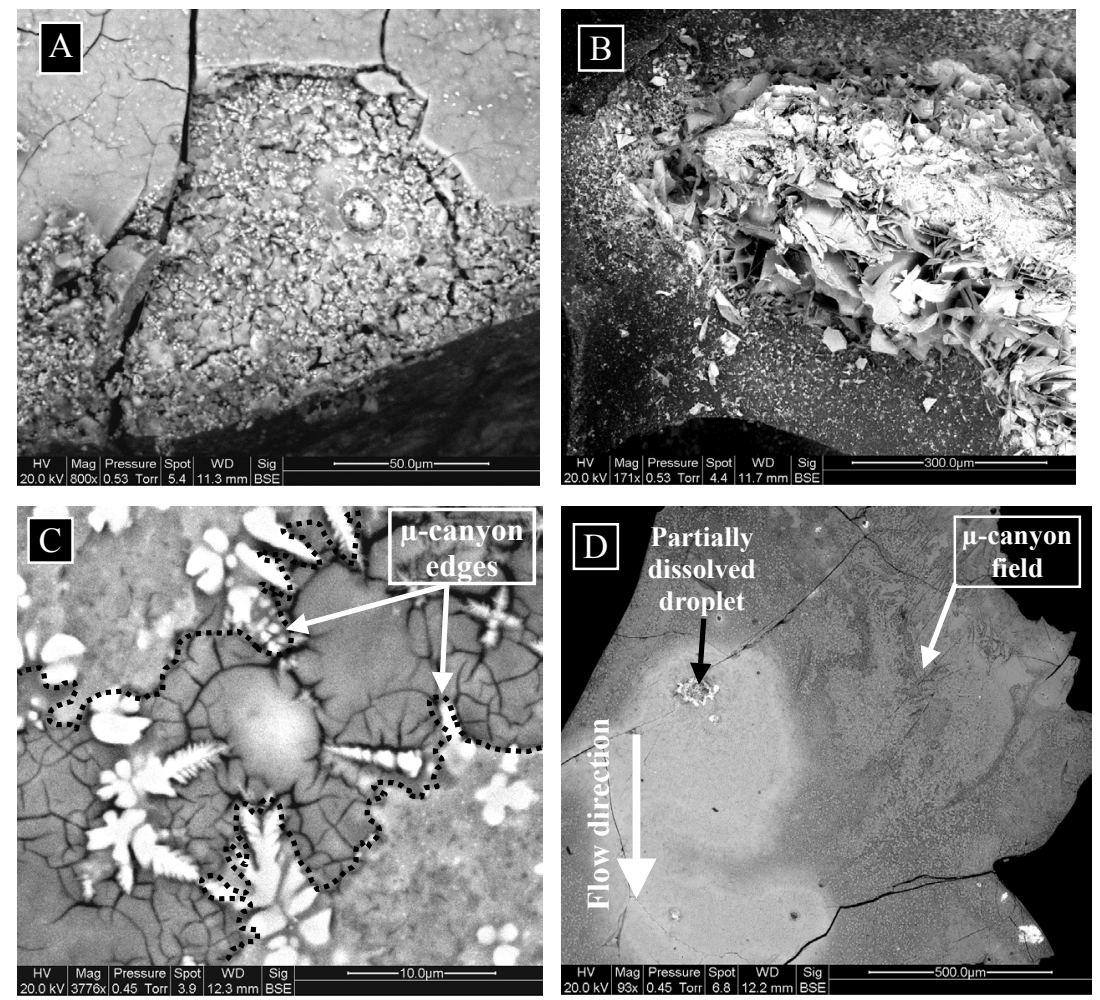

Figure 4: SEM images of waste surfaces altered in the different experiments: (A) and (B) in column, (C) and (D) in the polished section experiments.

Some ESEM images might be consistent with $[16,18]$ results showing lead sorption are supposed to happen in conditions similar to such influenced zones. Nevertheless no such evidence has been found with EDS punctual analyses. In altered zones, preliminary EDS analyses treatment may indicate that $\mathrm{Ca}$ is 
generally highly released conversely to $\mathrm{Si}$, which releasing rate may be assumed to be lower. In these zones, there is a relative Fe enrichment.

Table 1: $\quad$ Statistics of EDS analyses of fresh and altered glass ( $\%$ in weight).

\begin{tabular}{|l|l|l|l|l|}
\hline \multicolumn{2}{|c|}{} & $\mathrm{SiO}_{2}$ & $\mathrm{CaO}$ & $\mathrm{FeO}$ \\
\hline Fresh glass (167 analyses) & mean & 34.35 & 28.92 & 36.72 \\
\cline { 2 - 5 } & $\min$ & 24.54 & 24.61 & 26.30 \\
\cline { 2 - 5 } & $\max$ & 40.13 & 34.98 & 47.55 \\
\hline First slag level of the column (24 analyses) & mean & 13.78 & 3.12 & 83.10 \\
\cline { 2 - 5 } & min & 7.70 & 0.87 & 44.10 \\
\cline { 2 - 5 } & max & 36.02 & 36.02 & 91.44 \\
\hline Glass leached in container (21 analyses) & mean & 30.41 & 11.06 & 58.53 \\
\cline { 2 - 5 } & min & 10.39 & 4.63 & 45.01 \\
\cline { 2 - 5 } & max & 42.37 & 23.04 & 84.99 \\
\hline
\end{tabular}

\subsection{Outdoor weathering}

The results of this experiment are highly comparable to the polished section ones. During the glass alteration, there also is a Ca loss. However, the Si loss is more difficult to observe. Glass is also highly fractured and sometime lightens (Figure 5 A). Some micro-canyons can be observed in the altered glass. Lead carbonates are smaller (Figure 5 B) and apparently amorphous lead deposits which have not been observed in the laboratory experiments are here visible. Suspicion of sorption phenomena might be rarely observed on iron oxides near lead droplets. Thus, slags altered in weathering conditions may have a globally similar behaviour than in laboratory experiments.
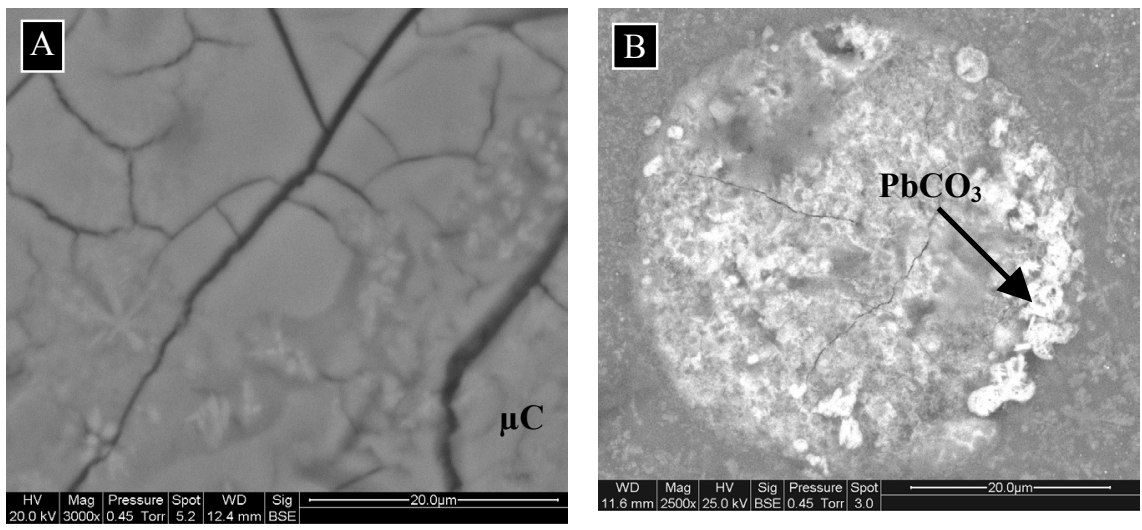

Figure 5: (A) altered glass matrix with fractures and micro-canyons $(\mu \mathrm{C})$ both induced by leaching, (B) altered lead droplets and lead carbonates. 


\section{Conclusion}

The laboratory experiments proposed here are useful to study the behaviour of $\mathrm{Pb}$ and $\mathrm{Zn}$ during metallurgical slag weathering. Indeed, they globally conduct to a comparable waste evolution than observed when altered in climatic conditions. It appears that when in contact with pure water in open flow conditions, slag releases relatively high and constant amounts of pollutants $(\mathrm{Pb}, \mathrm{Zn})$. It is linked to combined dissolution effects affecting glass and lead droplets. The advance of the glass alteration may be doped by big droplet dissolution. Pollutant immobilization may occur by lead carbonate formation but lead sorption on glass might be a minor mechanism. Nevertheless, complementary investigations (FIB, TEM-EDS, XANES...) will be necessary to better describe pollutant releases and glass leaching mechanisms.

\section{Acknowledgements}

This work is supported by the Nord-Pas-de-Calais region Council and the French Agency of Environment (ADEME). We would like to thank every Engineer who has helped us to use the ESEM (S. Gouy and P. Recourt) and the ICP-AES (B. Malet, J.-F. Barthe).

\section{References}

[1] Sobanska, S., Ledésert, B., Deneele, D., Laboudigue, A., Alteration in soils of slag particles resulting from lead smelting. Comptes Rendus de l'Académie des Science de Paris, Earth and Planetary Sciences, 331, pp. 271-278, 2000.

[2] Deneele, D., Caractérisation, simulations experimentales et thermodynamiques de l'altération de déchets vitreux. Unpublished University PhD Thesis, University of Lille1, France, pp. 187, 2002.

[3] Gervais, C., Evaluation environnementale des perspectives de valorisation en BTP de scories de premières fusion de plomb et de zinc. Unpublished PhD Thesis, Institut National des Sciences Appliquées de Lyon, France, pp. 218, 1999

[4] Ettler, V., Mihaljevic, M., Touray, J.C., Piantone, P., Leaching of polished sections: an integrated approach for studying the liberation of heavy metals from lead-zinc metallurgical slags. Bulletin de la Société Géologique de France, 173(2) pp.161-169, 2002.

[5] Barna, R., Moszkowicz, P., Gervais, C., Leaching assessment of road materials containing primary lead and zinc slags. Waste Management, 24, pp. 945-955, 2004.

[6] Ettler, V., piantone, P., Touray, J.C., Mineralogical control on inorganic contaminant mobility in leachate from lead-zinc metallurgical slag: experimental approach and long-term assessment. Mineralogical Magazine, 67(6), pp. 1269-1283, 2003. 
[7] Ettler, V., Komarkova, M., Jehlicka, J., Coufal, P., Hradil, D., Machovic, V., Delorme, F., Leaching of lead metallurgical slag in citric solutions implications for disposal and weathering in soil environments. Chemosphere, 57, pp. 567-577, 2004.

[8] Ettler, V., Jehlicka, J., Masek, V., Hruska, J., The leaching behaviour of lead metallurgical slag in high-molecular-weight (HMW) organic solutions. Mineralogical Magazine, 69(5), pp. 737-747, 2005.

[9] Perret, D., Crovisier, J.L., Stille, P., Shields, G., Mäder, U., Advocat, T., Schenk, K., Chardonnens, M., Thermodynamic stability of waste glasses compared to leaching behaviour. Applied Geochemistry, 18, pp. 1165-1184, 2003.

[10] Wolff-Boenisch, D., Gislason, S.R., Oelkers, E.H., Putnis, C. V., The dissolution rates of natural glasses as a function of their composition at $\mathrm{pH}$ 4 and 10.6, and temperature from 25 to $74^{\circ} \mathrm{C}$. Geochimica et Cosmochimica Acta, 68(23), pp. 4843-4858, 2004.

[11] Pisciella, P., Crisucci, S., Kamaranov, A., Pelino, M., Chemical durability of glasses obtained by vitrification of industrial wastes. Waste Management 21, pp. 1-9, 2001.

[12] Wang, P.W., Zhang, L., Structural role of lead silicate glasses derived from XPS spectra. Journal of Non-Crystalline Solids, 194 pp. 129-134, 1996.

[13] Karamarov, A., Pelino, M., Crystallization phenomena in iron-rich glasses. Journal of Non-Crystalline Solids, 281 pp; 139-151, 2001.

[14] Rossano, S., Ramos, A., Delaye, J.M., Creux, S., Filipponi, A., Brouder, Ch., Calas, G., EXAFS and Molecular Dynamics combined study od $\mathrm{CaO}-\mathrm{FeO}-2 \mathrm{SiO}_{2}$ glass. New insight into site significance in silicate glasses. Europhysics Letters, 49(5), pp. 597-602, 2000

[15] Seignez, N., Bulteel, D., Damidot, D., Gauthier, A., Potdevin, J.L., une nouvelle approche méthodologique pour caractériser l'altération d'un déchet industriel. Proc. of the first International Conference On Engineering for Waste Treatment, p 221, 2005

[16] Dimitrova, S.V., Metal sorption on Blast-Furnace slag. Water Research, 30(1), pp. 228-232, 1996.

[17] Dimitrova, S.V., Effect of the heat treatment on the morphology and sorption ability to metal ions of metallurgical slag. Journal of Materials Science, 36, pp. 2639-2643, 2001.

[18] Dimitrova, S.V., Use of granular columns for lead removal. Water Research, 36, pp. 4001-4008, 2002

[19] Benjamin, M.M.,. Leckie, J.O., Multiple-site adsorption of $\mathrm{Cd}, \mathrm{Cu}, \mathrm{Zn}$, and $\mathrm{Pb}$ on amorphous iron oxyhydroxide. Journal of Colloid and Interface Science, 79(1), pp. 209-221, 1981.

[20] Farley, K.J., Dzombak, D.A., Morel, F. M, A surface precipitation model for the sorption of cations on metal oxides. Journal of Colloid and Interface Science, 106(1), pp. 226-242, 1985. 